\title{
The Applicability of Agenda Setting Policy Implementation Theory on COVID-19 Lockdown Policy in Southern African Countries
}

\author{
Tariro Portia Tendengu \\ Social Work Lecturer at the Zimbabwe Ezekiel Guti University, Bindura, Zimbabwe \\ Email: portiatendengu@gmail.com
}

How to cite this paper: Tendengu, T. P. (2021). The Applicability of Agenda Setting Policy Implementation Theory on COVID19 Lockdown Policy in Southern African Countries. Open Journal of Political Science, 11, 549-559.

https://doi.org/10.4236/ojps.2021.113035

Received: February 24, 2021

Accepted: July 23, 2021

Published: July 26, 2021

Copyright ( 2021 by author(s) and Scientific Research Publishing Inc. This work is licensed under the Creative Commons Attribution International License (CC BY 4.0).

http://creativecommons.org/licenses/by/4.0/

\begin{abstract}
The COVID-19 outbreak has been declared a pandemic by international and governmental organisations in developed and developing countries. In Southern African countries, policy makers, Veto players and public policy advisors engaged in a policy dialogue so as to curb the COVID-19 pandemic by turning the outbreak of COVID-19 into an actionable government priority. COVID-19 pandemic in African countries presents a severe threat to human welfare of people living in rural and urban areas. Policy making involves a series of stages which have to be taken before a policy can be adopted to address an issue. The first stage involves identification of a problem and ensuring that it gets the attention of policy makers and is often referred to as agenda setting. Parsons (1995) termed this level "meso-analysis" where issues and problems are identified and agendas are set. Scholars have often argued that, agenda setting is an important tool in policy making as a decision making catalyst. This is based on the assumption that any government policy and action initiative needs someone to first bring it to their attention. In response to the $\mathrm{CO}$ VID-19 pandemic, agenda setting thus became a starting point for the identification of issues and possible policy instruments. The first stage involves identification of a problem and ensuring that it gets the attention of policy makers and is often referred to as agenda setting. Agenda setting with reference to the COVID-19 pandemic lockdown has been argued to be politically convoluted, it remains a process that involves a number of actors and institutions. The paper seeks to unravel the applicability of the Agenda setting theory as propounded by John Kindon on the implementation of the lockdown policy in Southern African countries.
\end{abstract}

\section{Keywords}

Agenda Setting Theory, Policy Implementation, Policy Dialogue, COVID-19, 
Lockdown Policy

\section{Introduction}

Later, African countries began to report COVID 19 cases hence lockdown was extended to African countries. Because of this extension the lockdown policy response to the COVID 19 pandemic was put in place after governments, veto players, policy makers and rational think tanks had widely consulted this as the most effective way to contain human-to-human transmission. To contain the COVID 19 pandemic, unprecedented measures are being taken globally. In Africa, at least 42 countries have imposed partial or full lockdowns on the movements and activities of their peoples (UN, 2020). Most African countries such as Cameroon the pandemic was transmitted by tourists, investors and travellers. In African countries such as Rwanda, Uganda, Botswana, Sudan, South Africa and Zimbabwe gatherings of more than 10 people were banned, and cafés, bars and movie theatres were closed. The COVID-19 pandemic caused Southern African countries embarked on a 21 day lockdown which was mainly aimed at curbing the spread of COVID 19. During this period schools, industries and markets were also closed to avoid social contact.

\section{Definition of Terms}

\subsection{Agenda Setting Theory}

Agenda setting is the process by which problems and alternative solutions gain or lose public and elite attention. Agenda setting refers to actually getting the "problem" on the formal policy agenda of issues to be addressed by presidents, cabinet members, Parliament, Congress, or ministers of health, finance, education, or other relevant ministries. Stakeholders outside of government can suggest issues to be addressed by policymakers, but government policymakers must become engaged in the process for a problem to be formally addressed through policy.

\subsection{COVID-19}

COVID-19 is a disease caused by a respiratory virus first identified in Wuhan, Hubei Province, China in December 2019. COVID-19 a new virus that hasn't caused illness in humans before. Worldwide, COVID-19 has resulted in thousands of human infections, causing illness and in some cases death. Cases have spread to countries throughout the world, with more cases reported daily.

COVID-19 has become a major pandemic. In a span of just 11 weeks from January to mid-March 2020, the virus has progressed from a discrete outbreak in Wuhan, China, to clusters of cases in many countries, and then to a pandemic with most countries reporting cases, and many experiencing significant outbreaks. Thus far, overall fatality rates have been higher than 3 percent, and considerably higher for older people and those with underlying health conditions. The virus is 
also affecting the health of younger adults (UN, 2020).

\section{Theoretical Background Information}

\section{The Agenda Setting Kingdon's (1995) Theory: Three Stream Theory}

The theory states that there are three streams of problems, politics and policies which flow independently but when they join/converge they form public policy

> Policies-policy options are made. Kingdon (1995) talks about the "Visible and hidden cluster" of actors with the visible being prominent participants like the president and congress actors and the hidden include actors operating from "federal/state agencies" The visible participants according to Kingdon (1995) play a pivotal role in the problem stream and in pushing issues or problems on the agenda of the government. Kingdon (1995: p. 116) also bring out the issue of "policy primordial soup"-problems float waiting to be taken up by government actors. Solutions move from the primordial soup through either softening up or coupling (ibid: 200-201). Softening up of the agenda can be done by interest groups, academics or researchers to ensure that the issues reach the agenda. Coupling refers to linking solutions with issues or challenges

> Politics-policy communities do share a problem especially to the experts, government, legislation, pressure groups, NGOs. Kingdon (1995) Key players in raising issues to awareness at national level are visible participants.

Policy window-where the three converge. Sometimes open allowing the streams to converge. Levels of integration of the streams determine policy success.

\section{Agenda Setting and the 5 Model Lockdown Strategy}

\subsection{Model Lockdown Strategy}

The outbreak of the COVID-19 in developed and developing countries affected the wellbeing of citizens. Governments, policy makers, veto players, grass root communities and rational decision think tanks formulated an agenda which was aimed at reducing the COVID-19 infections. The COVID-19 pandemic changed the economic landscape around the world including SADC region. As challenges mounted governments in Southern African countries during the COVID-19 pandemic policy makers, pressure groups, social action movements, and civil society organizations had to opt for a 5 model lockdown policy in addressing the devastating impacts of the COVID-19 pandemic. According to SADC (2020), it can be argued that the goal of the 5 model lockdown strategy in general was to control the pandemic by slowing down transmission and reducing mortality associated with COVID-19. In Southern African countries governments have been quick to put in place stringent 5 model lockdown measures which were aimed at containing the spread of COVID-19 (Miller, 2020). 


\subsection{Problem Recognition, COVID-19 and Agenda Setting}

The COVID-19 pandemic continued to evolve in Southern African countries, hence an effective policy had to be implemented to curb the pandemic. As proposed by the 5 model lockdown policy in Southern African countries, the success of the lockdown strategies will depend on the robustness of the safety-net measures put in place. Governments need to strengthen the social contract between state and citizen in the fight against COVID-19 and must adopt strict governance measures to ensure transparent targeting and use of resources (UN, 2020). The COVID-19 lockdown agenda is nothing more than "the list of subjects or problems to which governmental officials, and people outside the government closely associated with those officials, are paying some serious attention at any given time" (Kingdon, 1995: p. 3). While the government's (formal and informal) agenda presents the center of attention of studies on agenda-setting, the means and mechanisms of problem recognition and issue selection are tightly connected with the way a social problem is recognized and perceived on the public/media agenda.

As numerous studies since the 1960s have shown, problem recognition and agenda-setting are inherently political processes in which political attention is attached to a subset of all possibly relevant policy problems. In formulating the COVID-19 lockdown policy, actors within and outside government in Southern African countries constantly sought to influence and collectively shape the lockdown agenda by taking advantage of rising attention of the COVID-19 pandemic to a particular issue and advancing a particular problem definition. Experts in policy analysis and implementation advocated incremental ideas so as to curb the spread of COVID-19 pandemic. On a different note, it can be contested that the involvement of particular actors (e.g., experts), the choice of institutional venues in which problems are debated and the strategic use of media coverage have been identified as tactical means to define issues (cf. Kingdon, 1995; Baumgartner \& Jones, 1993).

\subsection{Policy Making and the 5 Lockdown Model}

Policy making involves a series of stages which have to be taken before a policy can be adopted to address an issue. Agenda setting thus becomes a starting point for identification of issues and possible policy instruments. The continuous cry by African countries on the spread of COVID-19 from western countries to African countries pressured African governments to initiate the lockdown policy. When community difficulties become prominent problems, with different groups and members raising their voices and calling for action, policy entrepreneurs put the issues on the policy agenda. Princen (2009) defines agenda setting as the process that involves the identification and analysis of problematic issues and bringing them to the attention of government so action can be taken through policies and policy instruments.

The COVID-19 lockdown policy implemented by European and African coun- 
tries supports the pluralist theory where government policies and action are believed to be in response of widespread public and popular demand (Hill, 2005). In this light policies will be adopted from the concerns of citizens. This could be noted in the implemented lockdown policy where policy makers, governments and rational think tanks in almost every country worldwide where consulted to give their input though policy dialogues and debates. Decision makers may simply be a recognition or legitimization of the voices of influence in the larger social matrix. On the other side there is also the elitist theory which identifies policies as emanating from individuals seated at the top of political and economic power structure (Hill, 2005). This can be seen as a top down approach.

\section{Power, Potency, Perception and Proximity}

\subsection{Power}

According to Zahariadis (2016), agenda setting proposed by Lippman the father of Agenda setting, rests on four key elements which are power, perception, proximity and potency. These are usually referred to as the four Ps and their contextual meaning in agenda setting and the COVID 19 lockdown policy will be discussed. Power is often argued to be the most influential element in agenda setting. According to Weber power is "the ability of an individual or group to achieve their own goals or aims when others are trying to prevent them from realizing them" (Wallimann et al., 1977). The COVID-19 outbreak contributed to hegemonic control by Southern African governments. Birkland (2015) highlighted that there are certainly some groups which are powerful than others and they are able to influence policy debates. For instance during the COVID 19 lockdown policy formulation, the implemented ideologies were in favor of elites, the government and rational think tanks. In Southern African countries, agenda problems and alternative solutions to the COVID-19 pandemic have been addressed by introducing social distancing policies, however these policies affected grass root communities.

As a result the study of policy process needs to be rooted in an extensive deliberation of the nature of power in the state (Hill, 2005). According to Peters and Pierre (2006) "the executive power executes what the legislative power has formulated and decided upon." This confirms the role played by power in agenda setting and policy formulation as there is need to consider who dominates in each stage of the process (Hill, 2005). Power can rest within political leaders who have the final say in decision making. This might be seen to be in support of the elitist model where important decisions are an agreement of a few elitists (Birkland, 2015). Power also involves having the financial muscle to implement a policy. However it can be argued that, many Southern African countries have been quick to put in place stringent measures aimed at containing the spread of the virus. Economic and social protection measures have lagged behind as policy makers face major liquidity and fiscal constraints (Miller, 2020). On a different note the lockdown policies were implemented in favor of governments fiscal 
policies. In Southern African countries such as Zimbabwe the government proposed the devolution of agenda in curbing COVID 19. The government of Zimbabwe is currently in the process of devolving the powers of central government, that is, the Executive and Treasury functions to the local governments of the 10 provinces (UN, 2020). The response to COVID-19 which requires greater coordination and policy programmatic direction from the centre could slow this noble policy stance of devolving power, authority and decision making to the sub-national level (UN, 2020).

\subsection{Potency}

Potency according to Zahariadis (2016) surrounds the intensity and graveness of a given issue as well as its consequences. Agenda setting emanates from trigger events or focusing events with the magnitude of the effects of such events determining government action (Birkland, 2015). For example it can be argued that, SADC member states including Angola, Botswana, Lesotho, Malawi, Mauritius, Mozambique, South Africa, Zambia and Zimbabwe had to regulate social distance. SADC member states should strengthen early warning systems response and mitigation of pandemics and disasters that have proved to be major threats to education, tourism and the informal sector as policy interventions and recommendations to keep economies afloat in the worst global economic downturn. The persistent and seemingly continuous spread of COVID-19 pandemic led the Southern African governments to come up with the lockdown policy so as to minimize the transmission of COVID 19.

\subsection{Perception}

Another important element is perception. This crucially defines how a problem is defined and viewed by different decision-makers. Kingdon (1995) argued that the process of turning an issue into an agenda needing governmental intervention also rests on the perceptual factor. During the COVID 19 agenda setting, policy makers, interest groups and decision makers identified and explained the issues surrounding COVID-19 pandemic so as to activate or deactivate support for an issue. The severe social effect of the coronavirus crisis was felt through the imposition of movement restrictions in many African countries. Some restrictive measures that were imposed and prioritised by the governments in Southern African countries to control the spread of corona virus include: restricting nonessential activities, closing schools and universities, encouraging people to stay home, the lockdown of entire cities, requiring essential businesses to run skeletal operations and employees should work from home (Ozili, 2020). As a result of the devastating effects of COVID-19 pandemic decision-makers had to reconsider measures that were to be implemented in addressing the COVID-19 pandemic. These measures inevitably affected economic activities in African countries, and policymakers had to use economic policies, both fiscal and monetary policies, to mitigate the negative effect on the economy (Ozili, 2020). Many Afri- 
can countries deployed the national budget and Central Bank's support in developing policies to mitigate the health and economic crises. Generally, the policy response in several African countries is country-specific because African countries are not closely intertwined.

\subsection{Proximity}

Proximity is based on the understanding that people are more likely to pay attention to issues that are closer to them and have a direct effect on them. The outbreak of COVID 19 in Western countries stimulated other neighboring countries and African countries to take stringent and extreme measures like travel bans to curb the spread of the diseases into their own nations. In addition nongovernmental organizations have thematic areas of focus where they are willing to put resources to solve issues. In African countries such as Zimbabwe organizations like Care International and World Vision strive to educate grass root communities on measures that can be taken so as to curb COVID-19 such as use of hand sanitizers to wash hands and maintaining social distancing at all costs. This supports Schattschneider (1960)'s argument that what is discussed on agenda setting depends on who brought the issue to attention which might also be linked to the earlier discussed power element hence these four Ps are important in agenda setting.

\section{The Applicability of Agenda Theory to the Lockdown Policy}

\subsection{Types of Agenda Setting}

There are three types of agenda setting: systematic agenda, political agenda and media agenda (Zahariadis, 2016). Other scholars have also added institutional agenda to the three.

\subsubsection{Systematic Agenda}

Systematic agendas are matters policy makers consider both worthy of note and consideration. Some scholars have termed it agenda universe encompassing all issues the public might view as requiring government action. Political agenda entails what the elites consider to be important issues for decision making (Rogers \& Dearing, 1988). This takes us back to the elitist model and power element.

\subsubsection{Political Agenda}

Political agenda has been labeled as an important element as "all events, processes and practices which occur within the social sphere have the potential to be political and are subject to political analysis (Hill, 2005). Mueller (1988) argued that politicians usually adopt a policy after weighing their gain either through political success or through program effectiveness. The lockdown policy has been hailed as a success and the Southern African Development Committee (SADC) referred to its success as a signal showing the prevention of COVID 19 pandemic. Princen (2009) argues that the best time to win a political battle is before the 
issue comes out on the agenda.

\subsubsection{Media Agenda}

The role of the media in informing people on pressing issues globally has been the roots of media agenda. During the outbreak of first COVID 19 pandemic cases, testing, treatment systems, preventative measures and lockdown exit strategies were published in international and local news papers. Mccombs and Shaw (1972) point out that often the media's priorities become the focus of policy makers. The media might not necessarily tell people what to think but it definitely skews people's minds on what to talk about (Mccombs \& Shaw, 1972).

Agenda setting describes the process by which the news media shows the public what is important by giving more salience to certain events and issues over others. According to agenda-setting theory, the public perceives issues that receive the most media coverage to be those of greatest importance (McCombs \& Shaw, 1972). The media's portrayal of COVID 19 pandemic was only that of the media's; viewers do not experience these events first hand. Therefore their own opinions originate more from the opinions of the news source.

\section{Components of the Agenda Setting Theory Applicable to the COVID 19 Lockdown Policy}

\subsection{Timing}

Timing is a key element in agenda setting theory applicable to the COVID 19 lockdown policy. Hill (2005) noted that in the event of a big wave (triggering event) problems, policies and politics maybe coupled to form policy agenda. The continuous spread of COVID 19 pandemic in developed and developing countries led to the implementation of the COVID 19 lockdown policy. Maintaining a lockdown may pose an immediate economic cost, but offers two great advantages. First, it provides "extra time" to put in place the systems needed to better suppress the disease's spread and to treat those who do contract it, by upgrading health care system capacity; implementing preventive measures in workplaces, schools and public places; and educating and engaging with communities on COVID-19 (UN, 2020). Kingdon (1995) argued that for a problem to be considered into policy agendas a solution or alternative should be available. Policy entrepreneurs set solutions through speeches, reports, legislative meetings and journals (Kingdon, 1995). However it can be contested that, Schattschneider's theory of conflict expansion has also been used to explain agenda setting. Birkland (2015) argues that various groups always fight to keep issues on the agenda. This theory is based on the view that issues are more likely to be elevated to agenda status if the scope is broadened (Birkland, 2015).

According to Birkland (2015), groups can go public with a problem utilizing symbols and images that induce greater media and public sympathy for their cause. This approach is similar to Zahariadis (2016)'s perception and potency elements in agenda setting. Should this not work Birkland (2015) argues that 
groups can appeal to higher decision making level. An example would be Southern African countries calling for intervention of supra institutions in the implementation of the lockdown policy.

\subsection{Problem Definition}

Another key area in agenda setting is problem definition. Stone (1997) holds the view that problem definition emanates from a subjective description of an issue thus individuals, groups and actors define issues strategically so to back up the course of action they see to be most to be in their favor. Issue definition is important as it has the potential to lure previously uninterested groups (Baumgartner \& Jones, 1993). It can be closely linked to Zahariadas' perception element and Schattschneider's conflict expansion. Issue definition could have been utilized by the Zimbabwean government to involve the security force to participate in implementing the lockdown policy.

Nelson (1984) introduced another view in agenda setting referred to as valence issues. Nelson (1984) focuses on how public officials learn of a new problem, give it their attention and mobilize resources to respond to the problem. To Nelson (1984), "reality is in the eyes of the beholder". Valence issues might attract the attention of a few like issues of closing churches and religious places of worship during the COVID 19 PANDEMIC lockdown in Southern African countries it might be a focus for some supra state institutions but not necessarily from the majority populace.

Agenda setting is thus an important process in policy making. Though it has been argued to be politically convoluted it remains a process that involves a number of actors and institutions. Issues of potency, power, proximity and perception are important in determining whether an issue will gain policy makers attention. Such elements could be enhanced through problem definition and conflict expansion. Timing also plays a pivotal role as utilization of policy windows is crucial in agenda setting. Policy windows usually result from the convergence of three streams (policy, problem and political). Issues that make the COVID 19 pandemic lockdown policy an issue for discussion can emanate from systematic agenda or public concern often called the pluralist theory whilst the reverse top down approach where policies are a construct of a few elites forms the basis of elitist theory. Closer analysis of these elements reviews how issues make it to the policy agenda and how others fail to make it.

The problem stream can emanate from triggering events like a sudden crisis, unemployment rates, and inflation rates among others. Peters and Pierre (2006) point out that polices gain public attention when there is a crisis or disaster. The political stream consists of "policy entrepreneurs" and includes politicians, civil servants or pressure group leaders who have issues they wish to put on the public agenda (Hill, 2005). Peters and Pierre (2006) argue that politicians are selfinterested and concerned on maximizing personal benefits. To Kingdon (1995) agenda setting emanates from policy windows growing from a convergence of the three and it's likely to last for a specific time just as windows are opened 
briefly and closed. This theory can be equated to the garbage-can model where agendas gain attention depending mostly on what else is happening in the system (Zahariadis, 2016).

\section{Research Finding and Conclusion}

The Agenda Setting theory as proposed by John Kingdon is pragmatic in responding to failing public policy formulation in Southern African countries. In responding to the effects of COVID-19 pandemic, policy makers and entrepreneurs introduced legislation and policies to address the consequences of COVID-19. Kingdon argues, that policy entrepreneurs are able to attach their solution to a problem, thereby insuring a successful policy outcome, which Kingdon defines as enacted legislation. Lockdown policies in Southern African countries were policy solutions to the consequences of COVID-19. It can be argued that, central to Kingdon's theory is a distinction between agenda-setting and the "generation of policy alernatives," or solutions. Agenda-setting may change suddenly, but solutions evolve incrementally over time. For example in Southern African countries such as Zimbabwe, policy analysts were rational in implementing fiscal policies that promote transparency and accountability so as to curb the COVID-19 pandemic. However it can be argued that, the Immediate Socio-Economic Response to COVID-19 in Zimbabwe Framework for Integrated Policy Analysis and Support require adaptation and review but nonetheless it is conceived as a veritable platform for collective commitment to accompany the government and people of Zimbabwe in responding to the COVID-19 pandemic.

The hypothesis supported by this research include that policy making during COVID 19 pandemic is more likely to be influenced by interest groups, veto players, political analysts, the government and civil society organisations.

\section{Conclusion}

Agenda setting is thus an important process in policy making. Though it has been argued to be politically convoluted it remains a process that involves a number of actors and institutions. The adjustment of lockdown measures as proposed by the 5 model lockdown strategy affected Sothern African countries as it was taken at once, issues relating to adjusting measures from sub-national level to local community level starting with communities which had the lowest cases of COVID-19 pandemic were partially recognized by policy makers and veto players. On the same note, it can be crystallized that lockdown measures had to be eased in a controlled manner by assessing the intervals and adverse effects of the lockdown policies in Southern African countries. Issues of potency, power, proximity and perception are important in determining whether an issue will gain policy makers attention. Such elements could be enhanced through problem definition and conflict expansion. Timing also plays a pivotal role as utilization of policy windows is crucial in agenda setting. Policy windows usually result from the convergence of three streams (policy, problem and political). Issues 
that make it to agenda setting can emanate from systematic agenda or public concern often called the pluralist theory whilst the reverse top down approach. Closer analysis of these elements reviews how issues make it to the policy agenda and how others fail to make it.

\section{Conflicts of Interest}

The author declares no conflicts of interest regarding the publication of this paper.

\section{References}

Baumgartner, F. R., \& Jones, B. D. (1993). Agendas and Instability in American Politics. Chicago, IL: University of Chicago Press.

Birkland, T. A. (2015). An Introduction to the Policy Process. London: Routledge. https://doi.org/10.4324/9781315717371

Hill, M. (2005). The Public Policy Process (4th ed.). London: Pearson Education Limited.

Kingdon, J. D. (1995). Agendas, Alternatives and Public Policies (2nd ed.). Boston, MA: Little, Brown and Company.

McCombs, M. E., \& Shaw, D. L. (1972) The Agenda-Setting Function of Mass Media. Public Opinion Quarterly, 36, 176-187. https://doi.org/10.1086/267990

Miller, M. (2020). Financing the Corona virus Response in Sub-Saharan Africa.

Mueller L. (1988). The Telephone War: Interconnection, Competition, and Monopoly in the Making of Universal Telephone Service, 1894-1920. Philadelphia, PA: University of Pennsylvania.

Nelson, B. J. (1984). Making an Issue of Child Abuse. Chicago, IL: University of Chicago Press.

Ozili, N. (2020). COVID-19 in Africa: Socio-Economic Impact Policy Response and Opportunities. International Journal of Sociology and Social Policy. https://doi.org/10.1108/IJSSP-05-2020-0171

Parsons, W. (1995). Public Policy: An Introduction to the Theory and Practice of Policy Analysis. Cheltenham: Edward Elgar.

Peters, E., \& Pierre, J. (2006). Handbook of Public Policy. London: Sage Publications.

Princen, S. (2009). Agenda Setting in the European Union. New York: Palgrave. https://doi.org/10.1057/9780230233966

Rogers, E. M., \& Dearing, J. W. (1988). Agenda-Setting Research: Where Has It Been? Where Is It Going? Communication Yearbook, 11, 555-594. https://doi.org/10.1080/23808985.1988.11678708

Schattschneider, E. E. (1960). The Semi-Sovereign People: A Realist's View of Democracy in America. New York: Holt, Rinehart and Winston.

Stone, D. (1997). Policy Paradox: The Art of Political Decision Making. New York: W. W. Norton \& Company.

UN (2020). COVID 19 Lockdown Exit Strategies for Africa. Addis Ababa: Economic Commission for Africa.

Wallimann, I., Tatsis, N., \& Zito, G. V. (1977). On Max Weber's Definition of Power. Journal of Sociology, 13, 231-235. https://doi.org/10.1177/144078337701300308 http://journals.sagepub.com/doi/abs/10.1177/144078337701300308

Zahariadis, N. (2016). Handbook on Public Policy. Cheltenham: Edward Elgan Publishing. https://doi.org/10.4337/9781784715922 